\title{
ANALYSIS OF GROUND WATER RESOURCES
}

\author{
Dr. S.K.Mittal ${ }^{1}$, Dr. Rekha Jain ${ }^{2}$, Dr. Yogesh K. Garg ${ }^{3}$, Ajay K. Gedam ${ }^{4}$ \\ Maulana Azad National Institute of Technology, \\ Bhopal (M.P.) INDIA
}

\begin{abstract}
Ground water development depends on many factors viz. availability, crop water requirement, socioeconomic fabric and on the yield of the aquifers existing in that area. The yields of wells are functions of the permeability and transmissivity of aquifer encountered and varies with location, diameter and depth etc. Ground water in the area is being developed by two type of abstraction structures i.e., borewells and dugwells. However dugwells are the main ground water abstraction structures in the district. The yield of such structures varies from 20 to $380 \mathrm{~m}^{3} /$ day. High yielding dugwells are generally located in weathered and fractured Basalts, fractured granites and Gondwana formations occurring in physiographic depressions.

The minor irrigation census data (2000-01) indicates that area irrigated by ground water is 914.68 sq.km., whereas surface water accounts for 341.74 sq.km. of area and net irrigated area stands at 1256.42 sq.km., Thus it is clear that ground water is the major source of irrigation as it accounts for about $73 \%$ of net irrigated area. The district had 59407 irrigation dugwells, which create an irrigation potential of 1413.71 sq.km. out of which 1236.25 sq.km. of irrigation potential is utilized. In addition of this 12.00 sq.km. of irrigation potential is utilized through 533 borewells/tubewells.

State government has drilled large number of borewells fitted with hand pumps and electric motors for rural drinking water purposes in the district. The GSDA, Government of Maharashtra till 2006-07 has constructed about 9953 borewells for rural water supply, out of which 9483 are fitted with hand pumps whereas 470 are fitted with electric pumps. The borewells have depth range of 40 to $70 \mathrm{~m}$ with the yield range from poor to more than $10000 \mathrm{lph}$.
\end{abstract}

Keywords: borewell, ground water, monsoon, rainfall, soil type

\section{Introduction}

Nagpur district is one of the nine districts of Vidharbha Region of Maharashtra State. It is situated on the eastern part of the State abutting Chindwada district of Madhya Pradesh in north. It is bounded by Wardha and Amravati districts in the west, Bhandara district in the east and Chandrapur district in the south. It lies between north latitudes $20^{\circ} 35^{\prime}$ and $21^{\circ} 44^{\prime}$ and east longitudes $78^{\circ} 15^{\prime}$ and $79^{\circ} 40^{\prime}$ and falls in Survey on India topo-sheets 55
$\mathrm{K}, \mathrm{O}$ and $\mathrm{P}$. The district has a geographical area of 9892 sq.km.

The district headquarters is located at Nagpur Town. For administrative convenience, the district is divided in 14 talukas viz, Nagpur (Urban), Saoner, Parseoni, Ramtek, Mouda, Kamthi, Kuhi, Bhiwapur, Umrer, Nagpur (Rural), Hingna, Katol, Narkheda and Kalmeshwar. It has a total population of 40.51 lakh as per 2001 census. The district has 29 towns, 1562 inhabited villages and 
312 uninhabited villages. The district forms part of Godavari basin. Wainganga River is the main river flowing through the district.

\section{Climate and Rainfall}

The climate of the district is characterized by a hot summer and general dryness throughout the year except during the south-west monsoon season, i.e., June to September. The mean minimum temperature is $12^{\circ} \mathrm{C}$ and mean maximum temperature is more than $45^{\circ} \mathrm{C}$.
Rainfall data from six rain gauge stations for the periods 1901 to 1999 have been analyzed. The salient features of the analyses are presented in Table-3. The normal annual rainfall over the district ranges from about $1000 \mathrm{~mm}$ to $1200 \mathrm{~mm}$. it is the minimum in the western parts around Katol $(985.4 \mathrm{~mm})$ and increases in the eastern direction and reached a maximum around Umrer (1213.6mm).

\begin{tabular}{|c|c|c|c|c|c|c|c|c|c|c|}
\hline \multirow[t]{2}{*}{ Station } & \multirow{2}{*}{$\begin{array}{l}\text { No. of } \\
\text { years }\end{array}$} & \multirow{2}{*}{$\begin{array}{l}\text { Annual } \\
\text { Normal } \\
\text { Rainfall } \\
(\mathrm{mm})\end{array}$} & \multirow{2}{*}{$\begin{array}{l}\text { Co- } \\
\text { efficient } \\
\text { of } \\
\text { variation } \\
(\%)\end{array}$} & \multicolumn{3}{|l|}{ proughts } & \multicolumn{3}{|c|}{$\mathrm{No} / \%$ of years with } & \multirow{2}{*}{$\begin{array}{l}\text { Rainfall } \\
\text { rrend } \\
\text { (mm/yr. }\end{array}$} \\
\hline & & & & Moderate & Severe & Acute & $\begin{array}{l}\text { eNormal } \\
\text { rainfall }\end{array}$ & $\begin{array}{l}\text { Normal } \\
\text { rainfall }\end{array}$ & $\begin{array}{l}\text { Excess } \\
\text { rainfall }\end{array}$ & \\
\hline Nagpur & 99 & 1175.5 & 23 & $17 /(17)$ & & & $45 /(45)$ & $45 /(45)$ & $15 /(15)$ & -1.97 \\
\hline Katol & 98 & 985.4 & 23 & $13 /(13)$ & & 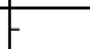 & $52 /(53)$ & $46 /(47)$ & $13 /(13)$ & -0.61 \\
\hline Ramtek & 98 & 1169.6 & 25 & $18 /(18)$ & - & - & $47 /(48)$ & $51 /(52)$ & $17 /(17)$ & -1.37 \\
\hline Parseoni & 63 & 1052.6 & 24 & $10 /(16)$ & $1(2)$ & & $31 /(49)$ & $32 /(51)$ & $8 /(13)$ & 0.64 \\
\hline Umrer & 98 & 1213.6 & 25 & $20 /(20)$ & & & $49 /(50)$ & $49 /(50)$ & $17 /(17)$ & -2.15 \\
\hline Saoner & 89 & 1029.3 & 24 & $13 /(15)$ & & & $46 /(50)$ & $43 /(48)$ & $17 /(19)$ & -1.62 \\
\hline
\end{tabular}

\section{SALIENT FEATURES OF RAINFALL ANALYSIS OF NAGPUR DISTRICT}

\section{Geomorphology and Soil Types}

The district forms part of Deccan Plateau having flat topped and terraced features. Eastward and northeastwards the landscape changes due to the change in the underlying rocks. The rocks of Gondwana series present a low rolling topography with a poor soil cover and vegetation. On the north the upland ranges are the extension of Satpuras which gradually narrows down towards west. South of these upland range stretches the Ambegad hills, the western extremity of which is the Nagpur district. The Ramtek temple is on the spur of this range. The Girad hill range extends along the southeast and separates the valley of the Kar from that of Jamb upto Kondhali. Another main hill range runs northwards through Katol taluka from Kondhali to Kelod separating the Wardha and
Wainanga valleys. The northeastern and east central parts of the district is dranined by the Wainganga and its tributaries. The central and western portion is drained by the Wena which is a tributary of Wardha river.

There are six types of soils found in Nagpur District. The details are as follows:

1) Kali Soils: These are black cotton soils which are fine grained clayey in texture and varies in depth from $1 \mathrm{~m}$ to $6 \mathrm{~m}$ or more and retain moisture. They are found around Kalmeshwar, Saoner and Nagpur.

2) Morand Soils: These are predominant in the district. They are black cotton soils with higher percentage of lime than the Kali Soils. They are black, grey or light to 
dark brown in colour, clayey in texture and have a depth of about 1 to $3 \mathrm{~m}$.

3) Khardi Soils: They are shallow soils mixed with sand and found mainly in hills. These are grey in colour, clay loam in texture.

4) Bardi Soils: They are red gravel covered with boulders found on summits and slopes of trap hills and are less fertile in nature.

5) Kachchar Soils: They are mainly found in the banks of Kanhan river and are alluvial soils, loamy in nature and vary in depth from 1 to $3 \mathrm{~m}$.

6) Wardi Soils: They are red soils with a large amount of sand. They are shallower and clayey loam in nature. They are mainly found in the paddy tracts in the eastern part of the district. Ground Water Scenario.

\section{Water Level Trend (1998-2007)}

Analysis of water level trend indicates that during premonsoon period, rise in water levels has been recorded at only 8 stations and it ranges between negligible and 0.25 $\mathrm{m} /$ year (Chacher). Fall in water levels has been in the rest 29 stations in the range of $0.02 \mathrm{~m} /$ year (Katol) to $0.64 \mathrm{~m} /$ year (Parseoni). During postmonsoon period, rise in water levels has been recorded at 9 stations and it ranges from negligible to $0.24 \mathrm{~m} /$ year (Kothulna), whereas at 28 stations, fall in water levels ranging between $0.01 \mathrm{~m} /$ year (Ramtek) and 0.56 $\mathrm{m} /$ year (Sathnaori) is observed. Thus in major part of the district, both during pre and postmonsoon periods declining trend of water levels has been observed.

The premonsoon trend map was also prepared and same is presented. It shows that the fall in water level trend of up to 20 $\mathrm{cm} /$ year is observed in about $80 \%$ of the area, occupying entire north, central, western, south eastern parts of the district in entire Narkhed, Katol, Kalmeshwar, Savner, Parseoni, Hingna, Kuhi and Bhivapur talukas and in part of Mauda, Nagpur and Umred talukas. The rise of up to $20 \mathrm{~cm} /$ year has been observed in small area in parts of Mauda, Nagpur and Umred talukas. Thus the situation is quite critical in almost entire district and the future ground water conservation and recharge structures need to be prioritized in these areas. 


\begin{tabular}{|c|c|c|c|c|c|c|c|c|c|}
\hline Taluka & Area type & $\begin{array}{l}\text { Net annual } \\
\text { ground } \\
\text { water } \\
\text { availability } \\
\text { (ham/yr.) }\end{array}$ & \multicolumn{3}{|c|}{$\begin{array}{l}\text { Annual ground water draft } \\
\text { (ham/yr.) }\end{array}$} & $\begin{array}{l}\text { Allocation for } \\
\text { domestic \& } \\
\text { industrial } \\
\text { requirement } \\
\text { supply up to } \\
\text { next } 25 \text { years } \\
\text { (ham/yr.) }\end{array}$ & $\begin{array}{l}\text { Groundwater } \\
\text { availability for } \\
\text { future } \\
\text { irrigation } \\
\text { (ham/yr.) }\end{array}$ & $\begin{array}{l}\text { Stage of } \\
\text { groundwater } \\
\text { development } \\
(\%)\end{array}$ & Category \\
\hline \multirow[t]{2}{*}{ NAGPUR } & COMMAND & 198.71 & 32.39 & 9.97 & 42.36 & 19.94 & 146.37 & 21.32 & \multirow[t]{2}{*}{ Safe } \\
\hline & TOTAL & 6837.44 & 2459.68 & 379.14 & 2838.83 & 3758.28 & 3619.46 & 41.52 & \\
\hline \multirow[t]{3}{*}{ KAMTEE } & COMMAND & 5718.60 & 1605.01 & 339.00 & 1944.01 & 1677.99 & 3435.60 & 33.99 & \multirow[t]{3}{*}{ Safe } \\
\hline & NON & 705.99 & 380.12 & 57.47 & 437.59 & 114.94 & 210.93 & 61.98 & \\
\hline & TOTAL & 6424.59 & 1985.13 & 396.47 & 2381.60 & 0792.93 & 3646.53 & 37.07 & \\
\hline \multirow[t]{2}{*}{ HINGANA } & COMMAND & 696.32 & 211.15 & 34.23 & 245.38 & 68.45 & 416.71 & 35.24 & \multirow[t]{2}{*}{ Safe } \\
\hline & NON & 7525.66 & 1857.59 & 401.93 & 2259.51 & 1763.48 & 4904.59 & 30.02 & \\
\hline \multirow[t]{3}{*}{ NARKHED } & COMMAND & 211.69 & 115.38 & 26.92 & 142.30 & 44.27 & 52.03 & 67.22 & \\
\hline & NON & 9184.49 & 6837.33 & 888.92 & 7726.25 & $5 \longdiv { 1 5 3 6 . 8 0 }$ & 1537.36 & 84.12 & \\
\hline & TOTAL & 9396.17 & 6952.72 & 915.83 & 7868.55 & 51581.07 & 1589.39 & 83.74 & \\
\hline \multirow[t]{3}{*}{ SAONER } & COMMAND & 3160.42 & 994.03 & 67.98 & 1062.01 & 192.16 & 2096.63 & 33.60 & \multirow[t]{3}{*}{ Safe } \\
\hline & NON & 3681.17 & 3467.50 & 275.84 & 3743.33 & 3180.25 & 725.84 & 101.69 & \\
\hline & TOTAL & 6841.59 & 4461.52 & 343.82 & 4805.34 & 4272.41 & 2822.47 & 70.24 & \\
\hline \multirow[t]{3}{*}{ KALMESHWAR } & COMMAND & 334.78 & 349.73 & 14.64 & 364.37 & 5.48 & 2.05 & 108.84 & \multirow[t]{3}{*}{ Safe } \\
\hline & NON & 6839.21 & 5014.18 & 302.17 & 5316.34 & 4572.95 & 1276.74 & 77.73 & \\
\hline & TOTAL & 7173.99 & 5363.91 & 316.81 & 5680.72 & \begin{tabular}{|l|l|}
278.43 \\
\end{tabular} & 1278.79 & 79.18 & \\
\hline
\end{tabular}

\begin{tabular}{|c|c|c|c|c|c|c|c|c|c|}
\hline Taluka & Area type & $\begin{array}{l}\text { Net annual } \\
\text { ground wate } \\
\text { availability } \\
\text { (ham/yr.) }\end{array}$ & $\begin{array}{l}\text { Annual g } \\
\text { r(ham/yr. } \\
\text { Irrigatior }\end{array}$ & $\begin{array}{l}\text { ground wate } \\
\text { Domestic } \\
\& \\
\text { industrial } \\
\text { uses }\end{array}$ & er draft & $\begin{array}{l}\text { Allocation for } \\
\text { domestic \& } \\
\text { industrial } \\
\text { requirement } \\
\text { supply up to } \\
\text { next } 25 \text { years } \\
\text { (ham/yr.) }\end{array}$ & $\begin{array}{l}\text { Groundwater } \\
\text { availability for } \\
\text { future } \\
\text { irrigation } \\
\text { (ham/yr.) }\end{array}$ & $\begin{array}{l}\text { Stage of } \\
\text { groundwater } \\
\text { development } \\
(\%)\end{array}$ & Category \\
\hline RAMTEK & \begin{tabular}{|l|} 
COMMAND \\
NON \\
TOTAL \\
\end{tabular} & \begin{tabular}{|l|}
2448.50 \\
4004.80 \\
6453.30 \\
\end{tabular} & \begin{tabular}{|l|}
289.54 \\
841.33 \\
1130.87 \\
\end{tabular} & \begin{tabular}{|l|}
133.81 \\
453.92 \\
587.73 \\
\end{tabular} & \begin{tabular}{|l|}
423.35 \\
1295.25 \\
1718.60 \\
\end{tabular} & \begin{tabular}{|l|}
256.38 \\
907.83 \\
$\mathbf{1 1 6 4 . 2 1}$ \\
\end{tabular} & \begin{tabular}{|l|}
1902.58 \\
2255.64 \\
4158.22 \\
\end{tabular} & \begin{tabular}{|l|}
17.29 \\
32.34 \\
26.63 \\
\end{tabular} & Safe \\
\hline PARSHIONI & \begin{tabular}{|l|} 
COMMAND \\
NON \\
TOTAL \\
\end{tabular} & \begin{tabular}{|l|}
6822.35 \\
1362.09 \\
8184.45 \\
\end{tabular} & $\begin{array}{l}638.09 \\
340.97 \\
979.06 \\
\end{array}$ & \begin{tabular}{|l|}
218.53 \\
73.50 \\
292.03 \\
\end{tabular} & \begin{tabular}{|l}
856.62 \\
414.47 \\
$\mathbf{1 2 7 1 . 0 9}$ \\
\end{tabular} & \begin{tabular}{|l|}
437.06 \\
146.99 \\
584.05 \\
\end{tabular} & \begin{tabular}{|l|}
5747.20 \\
874.13 \\
6621.33 \\
\end{tabular} & \begin{tabular}{|l|}
12.56 \\
30.43 \\
15.53 \\
\end{tabular} & Safe \\
\hline MOUDA & \begin{tabular}{|l|} 
COMMAND \\
NON \\
TOTAL \\
\end{tabular} & \begin{tabular}{|l|}
13711.98 \\
373.80 \\
14085.78 \\
\end{tabular} & \begin{tabular}{|l|}
1412.33 \\
88.68 \\
$\mathbf{1 5 0 1 . 0 1}$ \\
\end{tabular} & \begin{tabular}{|l|}
365.84 \\
43.93 \\
409.76 \\
\end{tabular} & \begin{tabular}{|l|}
1778.17 \\
132.61 \\
1910.78 \\
\end{tabular} & \begin{tabular}{|l|}
731.67 \\
87.86 \\
819.53 \\
\end{tabular} & \begin{tabular}{|l|}
11567.98 \\
197.26 \\
11765.24 \\
\end{tabular} & \begin{tabular}{|l|}
12.97 \\
35.48 \\
13.57 \\
\end{tabular} & Safe \\
\hline UMRED & \begin{tabular}{|l|} 
COMMAND \\
NON \\
TOTAL \\
\end{tabular} & \begin{tabular}{|l|}
1252.81 \\
8876.41 \\
10129.23 \\
\end{tabular} & \begin{tabular}{|l|}
163.79 \\
1643.17 \\
$\mathbf{1 8 0 6 . 9 6}$ \\
\end{tabular} & \begin{tabular}{|l|}
107.69 \\
324.42 \\
432.10 \\
\end{tabular} & \begin{tabular}{|l|}
271.47 \\
1967.59 \\
2239.07 \\
\end{tabular} & \begin{tabular}{|l|}
208.58 \\
648.84 \\
857.42 \\
\end{tabular} & \begin{tabular}{|l|}
880.45 \\
6584.40 \\
7464.85 \\
\end{tabular} & \begin{tabular}{|l|}
21.67 \\
22.17 \\
22.10 \\
\end{tabular} & Safe \\
\hline BHIWAPUR & \begin{tabular}{|l|} 
COMMAND \\
NON \\
TOTAL \\
\end{tabular} & \begin{tabular}{|l|}
441.48 \\
4378.02 \\
4819.49 \\
\end{tabular} & $\begin{array}{l}63.58 \\
985.71 \\
\mathbf{1 0 4 9 . 2 8} \\
\end{array}$ & \begin{tabular}{|l|}
54.29 \\
280.81 \\
335.10 \\
\end{tabular} & \begin{tabular}{|l|}
117.87 \\
1266.51 \\
$\mathbf{1 3 8 4 . 3 8}$ \\
\end{tabular} & \begin{tabular}{|l|}
108.59 \\
561.61 \\
670.20 \\
\end{tabular} & \begin{tabular}{|l|}
269.32 \\
2830.70 \\
3100.02 \\
\end{tabular} & \begin{tabular}{|l|}
26.70 \\
28.93 \\
28.72 \\
\end{tabular} & Safe \\
\hline $\mathrm{KUHI}$ & \begin{tabular}{|l|} 
COMMAND \\
NON \\
TOTAL \\
\end{tabular} & \begin{tabular}{|l|}
438.53 \\
7189.16 \\
7627.69 \\
\end{tabular} & \begin{tabular}{|l|}
123.68 \\
2189.78 \\
2313.46 \\
\end{tabular} & \begin{tabular}{|l|}
30.13 \\
472.05 \\
502.18 \\
\end{tabular} & \begin{tabular}{|l|}
153.81 \\
2661.83 \\
2815.64 \\
\end{tabular} & \begin{tabular}{|l|}
60.25 \\
944.10 \\
$\mathbf{1 0 0 4 . 3 5}$ \\
\end{tabular} & \begin{tabular}{|l|}
254.60 \\
4055.28 \\
4309.88 \\
\end{tabular} & \begin{tabular}{|l|}
35.07 \\
37.03 \\
36.91 \\
\end{tabular} & Safe \\
\hline \begin{tabular}{|l} 
DISTRICT \\
TOTAL
\end{tabular} & \begin{tabular}{|l|} 
COMMAND \\
NON \\
TOTAL \\
\end{tabular} & \begin{tabular}{|l|}
36069.72 \\
68119.30 \\
104189.02 \\
\end{tabular} & \begin{tabular}{|l|}
6548.42 \\
32882.31 \\
39430.73
\end{tabular} & \begin{tabular}{|l|}
1454.98 \\
14409.57 \\
5864.55
\end{tabular} & \begin{tabular}{|l|}
8003.40 \\
37291.88 \\
45295.28
\end{tabular} & \begin{tabular}{|l|}
2764.64 \\
37464.29 \\
10228.93
\end{tabular} & \begin{tabular}{|l|}
26848.84 \\
29913.60 \\
56762.44
\end{tabular} & \begin{tabular}{|l|}
22.19 \\
54.74 \\
43.47 \\
\end{tabular} & \\
\hline
\end{tabular}

GROUND WATER RESOURCES

\section{Ground Water Management}

\section{Strategy}

Ground water has special significance for agricultural development in the State of Maharashtra. The ground water development in some parts of the State has reached a critical stage resulting in decline of ground water levels.

The nature and yield potential of the aquifers occurring in different areas is given in perusal of shows that the 8 talukas i.e. Katol, Umred,Kamleshwar, Narkhed, Hingna, Kuhi, Mouda, Kamptee 
talukas have medium to high yield potential and the suitable abstraction structures are dugwell and DCB. However Katol and Narkhed talukas, which have been categorized as Semi-

\begin{tabular}{|c|c|c|c|c|c|c|c|c|c|}
\hline \multirow{2}{*}{$\begin{array}{l}\text { S. } \\
\text { No. }\end{array}$} & \multirow[t]{2}{*}{ Taluka } & \multicolumn{3}{|c|}{ Wells } & \multirow{2}{*}{$\begin{array}{l}\text { Depth } \\
\text { (mbgl) }\end{array}$} & \multirow{2}{*}{$\begin{array}{l}\text { SWL } \\
\text { (mbgl) }\end{array}$} & \multirow{2}{*}{$\begin{array}{l}\text { Dis- } \\
\text { charge } \\
\text { (Ips) }\end{array}$} & \multirow{2}{*}{$\begin{array}{l}\text { Draw- } \\
\text { Down } \\
\text { (m) }\end{array}$} & \multirow{2}{*}{$\begin{array}{l}\text { Zones } \\
\text { (mbgl) }\end{array}$} \\
\hline & & EW & OW & $P Z$ & & & & & \\
\hline 1. & Bhiwapur & 3 & 1 & 2 & \begin{tabular}{|l}
$36.5-$ \\
202.55
\end{tabular} & $\begin{array}{l}4.92- \\
5.3\end{array}$ & $0.38-1.37$ & & $22.0-140$ \\
\hline 2. & Hingna & 2 & 3 & & $\begin{array}{l}85.4- \\
234.8\end{array}$ & $\begin{array}{l}14.68- \\
27.65\end{array}$ & $0.5-$ & & \\
\hline 3. & Kalmeshwar & 9 & 4 & & $79.3-278$ & $\begin{array}{l}4.55- \\
28.5\end{array}$ & 7.92 & $\begin{array}{l}5.6- \\
11.95\end{array}$ & $28.0-107$ \\
\hline 4. & Kamthi & 6 & 3 & & $\begin{array}{l}29.93- \\
202.45\end{array}$ & $\begin{array}{l}4.53- \\
16.45\end{array}$ & $1.37-8.85$ & & $\overline{40.4}$ \\
\hline 5. & Katol & 6 & 3 & & $6.5-254$ & $\begin{array}{l}6.48- \\
28.3\end{array}$ & $1.05-38.5$ & $\begin{array}{l}9.76- \\
20.57\end{array}$ & $\begin{array}{l}12.19- \\
219.5\end{array}$ \\
\hline 6. & Kuhi & 4 & 3 & & $36.5-200$ & & & & $\begin{array}{l}5.0= \\
99.75\end{array}$ \\
\hline 7. & Mouda & 2 & 1 & & \begin{tabular}{|l|}
$174.5-$ \\
187.25 \\
\end{tabular} & 1.0 & $1.37-4.43$ & $\begin{array}{l}25.06- \\
42.58\end{array}$ & \begin{tabular}{|l|}
$34.75-$ \\
147.65
\end{tabular} \\
\hline 8. & Nagpur (R) & 2 & & 1 & \begin{tabular}{|l|}
$76.59-$ \\
159.45
\end{tabular} & 24.15 & $1.37-2.64$ & & $7.0-75.0$ \\
\hline 9. & Nagp & 1 & 1 & 1 & $\begin{array}{l}143.56- \\
300\end{array}$ & 10.05 & 0.03 & & $\begin{array}{l}21.5- \\
32.0\end{array}$ \\
\hline 10. & Narkhed & 3 & 1 & & $\begin{array}{l}181- \\
207.4\end{array}$ & $\begin{array}{l}1.19- \\
8.55\end{array}$ & 6.81 & $\begin{array}{l}1.29- \\
2.82 \\
\end{array}$ & \\
\hline 11. & Parseoni & 17 & 4 & 2 & \begin{tabular}{|l|}
$27.5-$ \\
199.64
\end{tabular} & $\begin{array}{l}4.05- \\
19.6\end{array}$ & $0.08-7.76$ & & $6-163.05$ \\
\hline 12. & Ramtek & 4 & 2 & & $\begin{array}{l}68.75- \\
214.75\end{array}$ & $\begin{array}{l}4.69- \\
5.05\end{array}$ & $0.14-4.43$ & $\begin{array}{l}3.42- \\
18.44\end{array}$ & \\
\hline 13. & Saoner & 8 & 17 & 1 & $43.0-307$ & $\begin{array}{l}2.30- \\
29.05\end{array}$ & $0.38-14.40$ & $\begin{array}{l}8.05- \\
31.06\end{array}$ & $\begin{array}{l}5.25- \\
140.2\end{array}$ \\
\hline 14. & Umred & 2 & & 2 & $67.5-200$ & \begin{tabular}{|l|}
$3.64-$ \\
5.07 \\
\end{tabular} & $0.01-2.16$ & & $24.0-122$ \\
\hline & TOTAL & 69 & 43 & 9 & $6.5-307$ & $\begin{array}{l}1.0- \\
29.05\end{array}$ & $0.01-38.5$ & $\begin{array}{l}1.29- \\
42.58\end{array}$ & $5-219.5$ \\
\hline
\end{tabular}

\section{SALIENT FEATURES OF} GROUND WATER EXPLORATION

\section{Water conservation and Artificial}

\section{Recharge}

Ground water plays vital role for irrigation in Nagpur district, as a result the ground water levels are depleting as faster rate. To avoid over-exploitation of ground water resources, there is a need to increase irrigation facilities from surface water sources and to conserve water flowing out from area through rivers ad nalas at various places by constructing different types of water conservation structures.
Critical needs careful planning for both ground water abstraction as well as augmentation, so that the sustainable development is achieved. 
and Kalmeshwar and 262 surrounding

villages. It was observed that ground water quality is adversely affected by nitrate contamination in various localities in eastern and southern part of Nagpur City. The zone is the end point for the entire municipal and domestic waste of the City discharged through Nag Nadi. This indiscriminate discharge of liquid waste in drain and on land, disposal of solid waste in land fill sites without hydro-geological consideration and microbial reaction in soil are contribution to high level Nitrate at these places. Such indiscriminate discharge of liquid and solid waste to $\mathrm{Nag}$ Nadi should be immediately stopped.

The following type of catchment and ground water recharge is suggested for this type of regions.

\begin{tabular}{|c|c|c|c|}
\hline No. & Region & Type of water & Use \\
\hline \multirow[t]{3}{*}{1} & \multirow[t]{3}{*}{ Arid plains } & $\begin{array}{l}\text { Artificial catchments to } \\
\text { capture rainfall }\end{array}$ & Drinking \\
\hline & & $\begin{array}{l}\text { Tanks or talabs to capture } \\
\text { surface run off }\end{array}$ & Drinking and irrigation \\
\hline & & $\begin{array}{l}\text { Embankments/obstructions } \\
\text { across drainage/Nalla to } \\
\text { capture surface run off }\end{array}$ & $\begin{array}{l}\text { Irrigation water and also for } \\
\text { recharging }\end{array}$ \\
\hline 2 & $\begin{array}{l}\text { Semi arid } \\
\text { places }\end{array}$ & $\begin{array}{l}\text { Tanks/ponds to capture surface run } \\
\text { off and also chains of tanks called } \\
\text { cascade }\end{array}$ & $\begin{array}{l}\text { Irrigation water and drinking } \\
\text { water through recharge of } \\
\text { ground water }\end{array}$ \\
\hline
\end{tabular}

\section{REFERENCES}

[1] Gogu, R.C. and A. Dassargues. (2000) Current trends and future challenges in groundwater vulnerability assessment using overlay and index methods. Environmental Geology, 39 (6): 549-559.

[2] Maxe, L. and Johansson, P.O. (1998) Assessing groundwater vulnerability using travel time and specific surface area as indicators. Hydrogeology Journal, 6:441-449.

[3] Nobre, R.C.M., Rotunno F.O.C., Mansur, W.J, Nobre, M.M.M., and Cosenza, C.A.N (2007) Groundwater vulnerability and risk mapping using GIS, modeling and a fuzzy logic tool. Journal of Contaminant Hydrology, 94:277-292

[4] Tesoriero, A.J., Inkpen, E .L and Voss, F.D. (1998). Assessing ground-water vulnerability using logistic regression. Proceedings for the Source Water Assessment and Protection 98 Conference, Dallas, $T X ; 157-65$.

[5] British Geological Survey. (2004) Community Management of Groundwater Resources: An Appropriate Response to Groundwater Overdraft in India? London, UK: British Geological Survey.

[6] Feitelson, E. (2006). Impediments to the Management of Shared Aquifers: A Political
Economy Perspective. Hydrogeology Journal 14(3):319-329

[7] Kalf, F.R.P. and Woolley, D.R. (2005). Applicability and Methodology of Determining Sustainable Yield in Groundwater Systems. Hydrogeology 13(1): 295312.

[8] Knegt, J..F and Vincent, L.F. (2001). From Open Access to Access by All: Restating Challenges in Groundwater Management in Andhra Pradesh. Natural Resources Forum 25(4):321-331.

[9] Planning Commission, Government of India. (2007). Report of the Expert Group on "Ground Water Management and Ownership". New Delhi, India: Government of India.

[10] Shah, T. (2000). Mobilizing Social Energy against Environmental Challenge: Understanding the Groundwater Recharge Movement in Western India. Natural Resource Forum 24(3):197-209

[11]CGWB. 2006. Dynamic ground water resources of India, Central Ground Water Board (CGWB), New Delhi. 